The Journal of Transport ANd LANd Use http://jtlu.org

Vol. 9 No. 1 [2016] pp. 1-7

JTLU

\title{
Introduction: The Journal of Transport and Land Use enters year nine
}

David Levinson

University of Minnesota

levin031@umn.edu

\section{Introduction}

With this issue, the Journal of Transport and Land Use enters its ninth volume (and many articles from volume 10 can be found online under Forthcoming). Since our last update (Levinson 2013), JTLU has continued to grow and expand. Many of the articles in the issues in this and next volume were selected from papers presented at the 2014 World Symposium on Transport Land Use Research in Delft, the Netherlands. We look forward to many more years of continued research and publication in this field.

\section{Relationship with WSTLUR}

We have established a formal relationship with the World Society for Transport and Land Use Research (WSTLUR). The 2017 World Symposium on Transport and Land Use Research will be held in Brisbane, Australia, and we hope to see many of you attending and taking note of cutting-edge research. Papers are due October 31, 2016. Details on the conference and the Call for Papers are available at the conference website (wstlur.org)

As part of that arrangement, it remains free for WSTLUR members to publish in JTLU. NonWSTLUR members are asked to pay $\$ 500$ for accepted articles to defray editing costs (anyone with access to a University Open Access fund is similarly asked to voluntarily contribute). Payment will not affect acceptance or lack thereof. As always, JTLU remains free to read.

\section{$3 \quad$ Indexing}

We are pleased to note that JTLU has been accepted for indexing in Social Science Citation Indexes and Current Contents/Social \& Behavioral Sciences by Thomson Reuters (beginning with 2013 issues, joining other indexing services Scopus, Google Scholar, and Directory of Open Access Journals (DOAJ).

Copyright 2016 David Levinson

http://dx.doi.org/10.5198/jtlu.2016.883

ISSN: 1938-7849 | Licensed under the Creative Commons Attribution - Noncommercial License 3.0

The Journal of Transport and Land Use is the official journal of the World Society for Transport and Land Use (WSTLUR) and is published and sponsored by the University of Minnesota Center for Transportation Studies. This paper and others from WSTLUR 2014 are also published with sponsorship from WSTLUR and the Institutes of Transportation Studies at University of California, Davis and University of California, Berkeley. 


\section{$4 \quad$ Editors}

We have added two new editors in the past year, Dick Ettema and Yingling Fan, who are replacing original editors Martin Dijst and Hong Lo. They join Ahmed El-Geneidy and Jan-Dirk Schmöcker, as well as myself. We thank Martin and Hong for their service.

\section{$5 \quad$ Metrics}

Figure 1 shows page views by year. We are heartened to continue a general rise. As the archive of articles in the vaults of JTLU grows, we would expect this number to continue upwards, though clearly page views are dominated by views of more recent articles and by prospective authors. (Monthly data shows spikes just before the WSTLUR deadline, for example.)

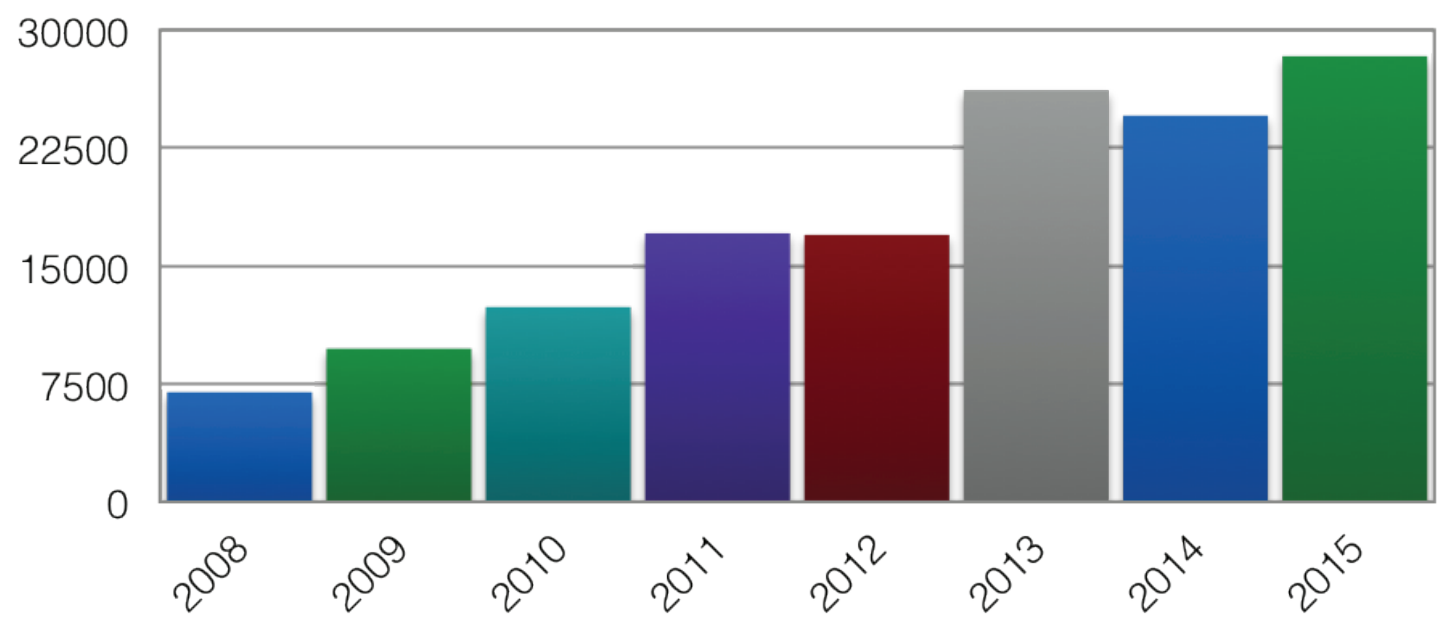

Figure 1: Visits to JTLU.org

We published 29 articles in 2015, 27 in 2014, and 22 in 2013. In Tables 1 through 3, we list the most widely read articles in each of those years. To be clear, we are aware that all such lists are inherently arbitrary; it is certainly possible for a paper to have just missed the cut-off in both 2014 and in 2015 but to have more views overall than many papers higher on either year's list, so this list gives only a flavor of metrics. One can imagine other metrics, but none is without features. Total views bias toward older papers; total views per day bias toward new papers. 
Table 1: Most-read papers in 2013 by page view

\begin{tabular}{|l|l|c|}
\hline Title & Author(s) & Volume and issue no. \\
\hline $\begin{array}{l}\text { How built environment affects travel } \\
\text { behavior: A comparative analysis of the } \\
\text { connections between land use and vehicle } \\
\text { miles traveled in US cities }\end{array}$ & $\begin{array}{l}\text { Lei Zhang, Jin Hyun Hong, } \\
\text { Arefeh Nasri, Qing Shen }\end{array}$ & $5(3)$ \\
\hline $\begin{array}{l}\text { Viewpoint: Assessing the reality-Trans- } \\
\text { port and land use planning to achieve } \\
\text { sustainability }\end{array}$ & David Banister & $5(3)$ \\
\hline $\begin{array}{l}\text { Explaining walking distance to public } \\
\text { transport: The dominance of public trans- } \\
\text { port supply }\end{array}$ & $\begin{array}{l}\text { Rhonda Daniels, Corinne } \\
\text { Mulley }\end{array}$ & $6(2)$ \\
\hline $\begin{array}{l}\text { Linking urban transport and land use in } \\
\text { developing countries }\end{array}$ & Robert B Cervero & $6(1)$ \\
\hline $\begin{array}{l}\text { What is mixed use? Presenting an interac- } \\
\text { tion method for measuring land use mix }\end{array}$ & $\begin{array}{l}\text { Kevin Manaugh, Tyler Kre- } \\
\text { ider }\end{array}$ & $6(1)$ \\
\hline $\begin{array}{l}\text { Metropolitan smart growth centers: An } \\
\text { assessment of incentive policies in four } \\
\text { regions }\end{array}$ & $\begin{array}{l}\text { Richard D Margerum, Susan } \\
\text { Brody, Robert Parker, Gail } \\
\text { McEwen }\end{array}$ & $6(2)$ \\
\hline $\begin{array}{l}\text { Does public transit use increase the eco- } \\
\text { nomic efficiency of urban areas? }\end{array}$ & $\begin{array}{l}\text { Mathew Drennan, Charles } \\
\text { Brecher }\end{array}$ & $6(2)$ \\
\hline $\begin{array}{l}\text { Modeling the land-use correlates of vehi- } \\
\text { cle-trip lengths for assessing the transporta- } \\
\text { tion impacts of land developments }\end{array}$ & $\begin{array}{l}\text { Sivaramakrishnan Srinivasan, } \\
\text { Russell Provost, Ruth Steiner }\end{array}$ & $6(2)$ \\
\hline $\begin{array}{l}\text { Development of a temporal and spatial } \\
\text { linkage between transit demand and land- } \\
\text { use patterns }\end{array}$ & $\begin{array}{l}\text { Sanggu Lee, Mark Hickman, } \\
\text { Daoqin Tong }\end{array}$ \\
\hline $\begin{array}{l}\text { Mobility, access, and choice: a new source } \\
\text { of evidence }\end{array}$ & David Metz & $6(2)$ \\
\hline
\end{tabular}


Table 2: Most-read papers in 2014 by page view

\begin{tabular}{|l|l|c|}
\hline Title & Author(s) & Volume and issue no. \\
\hline $\begin{array}{l}\text { Linking urban transport and land use in } \\
\text { developing countries }\end{array}$ & Robert B. Cervero & $6(1)$ \\
\hline $\begin{array}{l}\text { Information, communication, travel be- } \\
\text { havior and accessibility }\end{array}$ & $\begin{array}{l}\text { Bert van Wee, Karst Geurs, } \\
\text { Caspar Chorus }\end{array}$ & $6(3)$ \\
\hline $\begin{array}{l}\text { What is mixed use? Presenting an interac- } \\
\text { tion method for measuring land use mix }\end{array}$ & $\begin{array}{l}\text { Kevin Manaugh, Tyler Kre- } \\
\text { ider }\end{array}$ & $6(1)$ \\
\hline $\begin{array}{l}\text { Does travel behavior matter in defining } \\
\text { urban form? A quantitative analysis charac- } \\
\text { terizing distinct areas within a region }\end{array}$ & $\begin{array}{l}\text { Cynthia Jacques, Ahmed El- } \\
\text { Geneidy }\end{array}$ & $7(1)$ \\
\hline $\begin{array}{l}\text { Integrating people and place: A density- } \\
\text { based measure for assessing accessibility to } \\
\text { opportunities }\end{array}$ & Mark W Horner, Joni Downs \\
\hline Rail integrated communities in Tokyo & John Calimente & $7(2)$ \\
\hline $\begin{array}{l}\text { A brief introduction to London's under- } \\
\text { ground railways and land use }\end{array}$ & Nathan Darroch & $7(1)$ \\
\hline $\begin{array}{l}\text { Special section: Innovations in location } \\
\text { choice modeling underlying activity-travel } \\
\text { behavior }\end{array}$ & $\begin{array}{l}\text { Darren M. Scott, Brian Ho- } \\
\text { Yin Lee, Eric Miller }\end{array}$ & $7(1)$ \\
\hline $\begin{array}{l}\text { The role of location in residential location } \\
\text { choice models: a review of literature }\end{array}$ & $\begin{array}{l}\text { Patrick M. Schirmer, Michael } \\
\text { A.B. van Eggermond, Kay W. } \\
\text { Axhausen }\end{array}$ & $7(2)$ \\
\hline $\begin{array}{l}\text { How built environment affects travel } \\
\text { behavior: A comparative analysis of the } \\
\text { connections between land use and vehicle } \\
\text { miles traveled in US cities }\end{array}$ & $\begin{array}{l}\text { Lei Zhang, Jin Hyun Hong, } \\
\text { Arefeh Nasri, Qing Shen }\end{array}$ \\
\hline
\end{tabular}


Table 3: Most-read papers in 2015 by page view

\begin{tabular}{|l|l|c|}
\hline Title & Author(s) & Volume and issue no. \\
\hline $\begin{array}{l}\text { Viewpoint: Transport's digital age transi- } \\
\text { tion }\end{array}$ & Glenn Lyons & $8(2)$ \\
\hline $\begin{array}{l}\text { Transit-oriented development and the } \\
\text { frequency of modal use }\end{array}$ & $\begin{array}{l}\text { Robert B Noland, Stephanie } \\
\text { DiPetrillo }\end{array}$ & (Forthcoming) \\
\hline $\begin{array}{l}\text { Do characteristics of walkable environ- } \\
\text { ments support bicycling? Toward a defini- } \\
\text { tion of bicycle-supported development }\end{array}$ & $\begin{array}{l}\text { Christopher Muhs and Kelly } \\
\text { Clifton }\end{array}$ & 5(1) \\
\hline Rail integrated communities in Tokyo & John Calimente & $7(3)$ \\
\hline $\begin{array}{l}\text { Residential self-selection in the relation- } \\
\text { ships between the built environment and } \\
\text { travel behavior: Introduction to the special } \\
\text { issue }\end{array}$ & Jason Cao & $6(1)$ \\
\hline $\begin{array}{l}\text { Linking urban transport and land use in } \\
\text { developing countries }\end{array}$ & Robert B Cervero & $6(1)$ \\
\hline $\begin{array}{l}\text { What is mixed use? Presenting an interac- } \\
\text { tion method for measuring land use mix }\end{array}$ & $\begin{array}{l}\text { Kevin Manaugh, Tyler Kre- } \\
\text { ider }\end{array}$ & $8(1)$ \\
\hline $\begin{array}{l}\text { Trip generation: Introduction to the spe- } \\
\text { cial section }\end{array}$ & Susan Handy & $7(2)$ \\
\hline $\begin{array}{l}\text { Integrating people and place: A density- } \\
\text { based measure for assessing accessibility to } \\
\text { opportunities }\end{array}$ & Mark W Horner, Joni Downs & $8(1)$ \\
\hline $\begin{array}{l}\text { The influence of land use and mobility } \\
\text { policy on travel behavior: A comparative } \\
\text { case study of Flanders and the Netherlands }\end{array}$ & Jonas De Vos & 7 (1) \\
\hline
\end{tabular}




\section{References}

Banister, D. 2012. Assessing the reality-transport and land use planning to achieve sustainability. Journal of Transport and Land Use 5(3) 1-14. doi: 10.5198/jtlu.v5i3.388.

Calimente, J. 2012. Rail integrated communities in Tokyo. Journal of Transport and Land Use 5(1): 19-32. doi:10.5198/jtlu.v5i1.280.

Cao, J. 2014. Residential self-selection in the relationships between the built environment and travel behavior: Introduction to the special issue. Journal of Transport and Land Use 7(3): 1-3. doi:10.5198/ jtlu.v7i3.726.

Cervero, R. 2013. Linking urban transport and land use in developing countries. Journal of Transport and Land Use 6(1): 7-24. doi:10.5198/jtlu.v6i1.425.

Daniels, R.,and C. Mulley. 2013. Explaining walking distance to public transport: The dominance of public transport supply. Journal of Transport and Land Use 6(2): 5-20. doi:10.5198/jtlu.v6i2.308

Darroch, N. 2014. A brief introduction to London's underground railways and land use. Journal of Transport and Land Use 7(1): 105-116. doi:10.5198/jtlu.v7i1.411.

De Vos, J. 2015. The influence of land use and mobility policy on travel behavior: A comparative case study of Flanders and the Netherlands. Journal of Transport and Land Use 8(1): 171-190. doi:10.5198/jtlu.2015.709.

Drennan, M. P., and C. Brecher. 2012. Does public transit use increase the economic efficiency of urban areas? Journal of Transport and Land Use 5(3): 53-67. doi:10.5198/jtlu.v5i3.247.

Handy, S. 2015. Trip generation: Introduction to the special section. Journal of Transport and Land Use 8(1): 1-4. doi:10.5198/jtlu.2015.822.

Horner, M. W., and J. A. Downs. 2014. Integrating people and place: A density-based measure for assessing accessibility to opportunities. Journal of Transport and Land Use 7(2): 23-40. doi:10.5198/ jtlu.v7i2.417.

Jacques, C., and A. El-Geneidy. 2014. Does travel behavior matter in defining urban form? A quantitative analysis characterizing distinct areas within a region. Journal of Transport and Land Use 7(1): 1-14. doi:10.5198/jtlu.v7i1.377.

Lee, S. G., M. Hickman, and D. Tong. 2013. Development of a temporal and spatial linkage between transit demand and landuse patterns. Journal of Transport and Land Use 6(2): 33-46. doi:10.5198/ jtlu.v6i2.268.

Levinson, D. 2013. Introduction: The Journal of Transport and Land Use enters year six. Journal of Transport and Land Use 9(1): 1-5.

Lyons, G. 2015. Viewpoint: Transport's digital age transition. Journal of Transport and Land Use 8(2): 1-19. doi:10.5198/jtlu.2015.751.

Manaugh, K., and T. Kreider. 2013. What is mixed use? presenting an interaction method for measuring land use mix. Journal of Transport and Land Use 6(1): 63-72. doi:10.5198/jtlu.v6i1.291.

Margerum, R. D., S. Brody, R. Parker, and G. McEwen, G. 2013. Metropolitan smart-growth centers: An assessment of incentive policies in four regions. Journal of Transport and Land Use 6(2): 21-32. doi:10.5198/jtlu.v6i2.257.

Metz, D. 2013. Mobility, access, and choice: A new source of evidence. Journal of Transport and Land Use 6(2): 1-4. doi:10.5198/jtlu.v6i2.309.

Noland, R. B., \& Dipetrillo, S. 2015. Transit-oriented development and the frequency of modal use. Journal of Transport and Land Use 8(2): 21-44. doi:10.5198/jtlu.2015.517.

Schirmer, P. M., M. A. B. van Eggermond, and K. W. Axhausen. 2014. The role of location in residential location choice models: A review of literature. Journal of Transport and Land Use 7(2): 3-21. doi:10.5198/jtlu.v7i2.740. 
Scott, D. M., B. H. Y. Lee, and E. J. Miller. 2014. Special section: Innovations in location choice modeling underlying activity-travel behavior. Journal of Transport and Land Use 7(2): 1-2. doi:10.5198/ jtlu.v7i2.769.

Srinivasan, S., R. Provost, and R. Steiner. 2013. Modeling the land-use correlates of vehicle-trip lengths for assessing the transportation impacts of land developments. Journal of Transport and Land Use 6(2): 59-75. doi:10.5198/jtlu.v6i2.254.

van Wee, B., K. Geurs, and C. Chorus. 2013. Information, communication, travel behavior and accessibility. Journal of Transport and Land Use 6(3): 1-16. doi:10.5198/jtlu.v6i3.282.

Zhang, L., Hong, J., Nasri, A., and Q. Shen. 2012. How built environment affects travel behavior: A comparative analysis of the connections between land use and vehicle miles traveled in US cities. Journal of Transport and Land Use 5(3), 40-52. doi:10.5198/jtlu.v5i3.266. 